\title{
E-commerce Role of Fabric Industries
}

\author{
Sani Hendriansyah ${ }^{1}$, Tatik Fidowaty ${ }^{2}$ \\ \{ sanihendriansyah@mahasiswa.unikom.ac.id ${ }^{1}$, tatik.fidowaty@email.unikom.ac.id ${ }^{2}$ \}
}

Faculty of Engineering and Computer Science, Universitas Komputer Indonesia ${ }^{1}$, Faculty of Social and Political Sciences, Universitas Komputer Indonesia, Indonesia ${ }^{2}$

\begin{abstract}
This research aims to help business people in using e-commerce and increase the sales results in the marketing of a fabric industry in Bandung. So far, marketing system has been carried out in a manual system that is handled directly by the customer, which makes it time-consuming and costly. Along with the usage of E-commerce in various fields, it is also used in the sales of fabrics. Making a website is one of the multiple ways to increase sales. In the current era of globalization, internet usage and social media are mandatory for many merchants who utilize sales through E-Commerce. This study uses a descriptive method with a qualitative approach carried out in specific fabric industry. The results of this study are the increase in sales of the products and how websites can be utilized in industrial areas. This happens because in using E-Commerce, customers can ignore distance and time. whenever and wherever the customer no longer has to visit or buy the items directly to the store. The conclusion is that e-commerce systems make it easy for users to access information about fabric products online.
\end{abstract}

Keywords: e-commerce, business, marketing 


\section{Introduction}

Fabric is a type of textile material that can be processed in a way such as crossing several warp threads with feed fiber yarn. In textile fibers, it is divided into two groups which are natural fibers and artificial fibers. In artificial fibers, it is divided into two, namely semi-artificial fibers and synthetic fibers. Along with the development of interest and also the tastes of consumers who are concerned with their color variations and also the comfort of the fabric must be considered because it is a very important thing [1]. E-Commerce is a set of technologies that have been designed in such a way as to make sales based on applications or web browsers, and in business processes that can dynamically be linked between companies, consumers and certain organizations through electronic transactions [2].

In marketing strategy, it can be said that innovation helps product sales to be more profitable in e-commerce and every business needs to use unique strategies to support their marketing [3]. Other than facilitating the marketing process, the role of E-Commerce is important because E-Commerce shortens electronic commercials and has become a popular name for other terms related to electronic transactions [4]. E-commerce aims to facilitate all aspects of the business, it is also achieved more important aspects, including in creating opportunities for companies, organizations, and stores to reach customers more efficiently and create a better market [5]. With some efforts, it can achieve more in determining the formal wear industry business using offline-based or online-based, some people can also get income from the advertising which creates an additional business besides installing trade [6]. Ecommerce in the fabric industry has several benefits for fabric industries in the field of interface investment which causes E-commerce to be important [7].

Besides the benefits of e-commerce, there are several negative impacts which is an abuse of legal authority [8]. In the fabric industry, further efforts can increase marketing and sales. [9] With this method, entrepreneurs can describe the phenomenon of e-commerce and increase sales results in marketing the fabric industry [10]. this study can also use web-based information systems in industrial fabrics [11]. This is an effort that can increase marketing and sales in this fabric industry, and websites can be used for industrial areas. The conclusion is that e-commerce systems makes it easier for users to access information about fabric products online.

\section{Material and Method}

The method used in this research is descriptive method with a qualitative approach. The aim is to help business people in using e-commerce and increase the sales results in the marketing of a fabric industry in Bandung. The data collection technique uses observations, namely the method of collecting data by observing objects directly and recording systematically about what is going to be observed. The researcher made observations directly in the field of the fabric industry area and uses in-depth interviewing techniques to obtain valid data and facts. 


\section{Results and Discussion}

Fabric industry performs through E-commerce for the marketed type of fabric in which the customers can order products that are available on the web. This is very helpful for buyers in terms of time to get the desired product. The E-commerce system is convenient and comfortable for buyers.

First, the buyer is required to open the web and make a selection of the desired fabric; the seller must always update the types and availability of fabrics in the factory and on the website in an attempt to meet the consumer's desires. The website provides home, blog, contact, and how to order section in the main menu. The home display is the front page which only displays the description of the website; the contact of the seller is present on the contact menu. How to order menu only describes the procedure for ordering fabric products that the customer wanted which will be directed to the payment stage. The last menu shows the types of fabric on the website, the example:

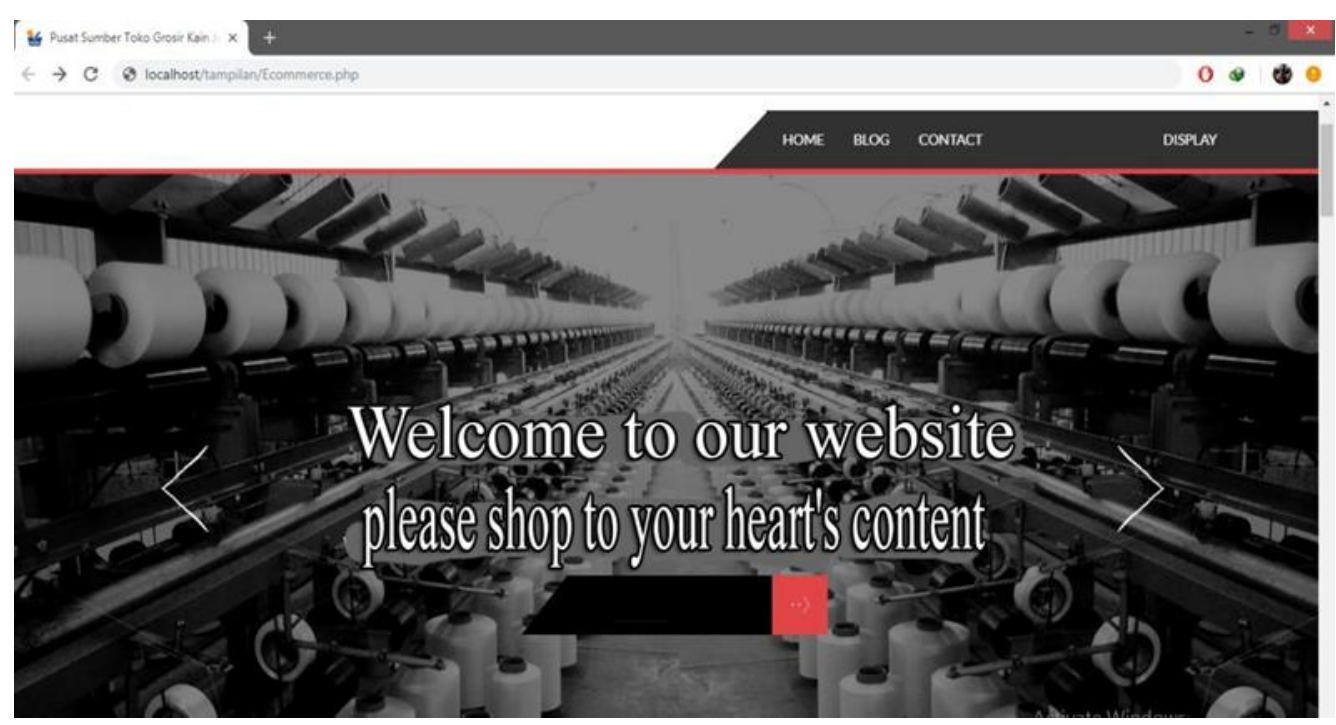

Fig. 1. Form Menu, this figure was adopted on 12 December 2018

The second display that is designed on the web contains a hot item menu, where the buyer can choose the desired fabric that has been provided by the seller with the price. The following is an example of the Website in Figure 2: 


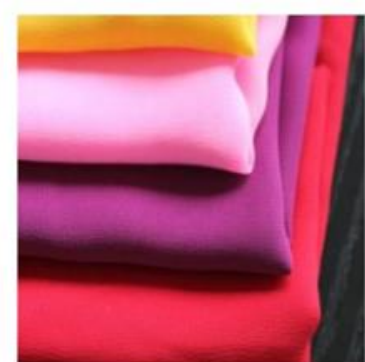

SIFON CHIFFON

Rp $15,000.00$

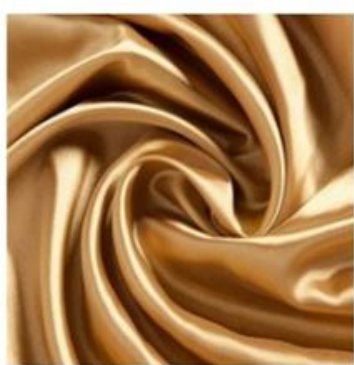

SATIN VELVET

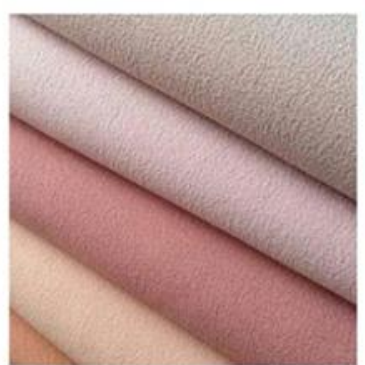

DIAMOND CERRUT

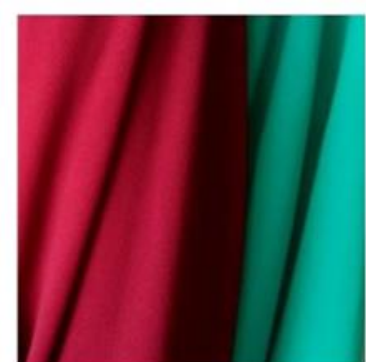

BUBBLE CREPE

Diamond Cerruti merupakan salah sa... <ul>< <ll> Tekstur timbul. Serupa bubbl.. Rp 25,000.00

Fig. 2. Detail of fabric, this figure was adopted on 12 December 2018

Furthermore, in this third view, there is a definition of the type of fabric that is chosen by consumers and also displays the type of fabric where customers can enter into the basket to proceed into the payment stage. The following is an example of the Website in figure 3:

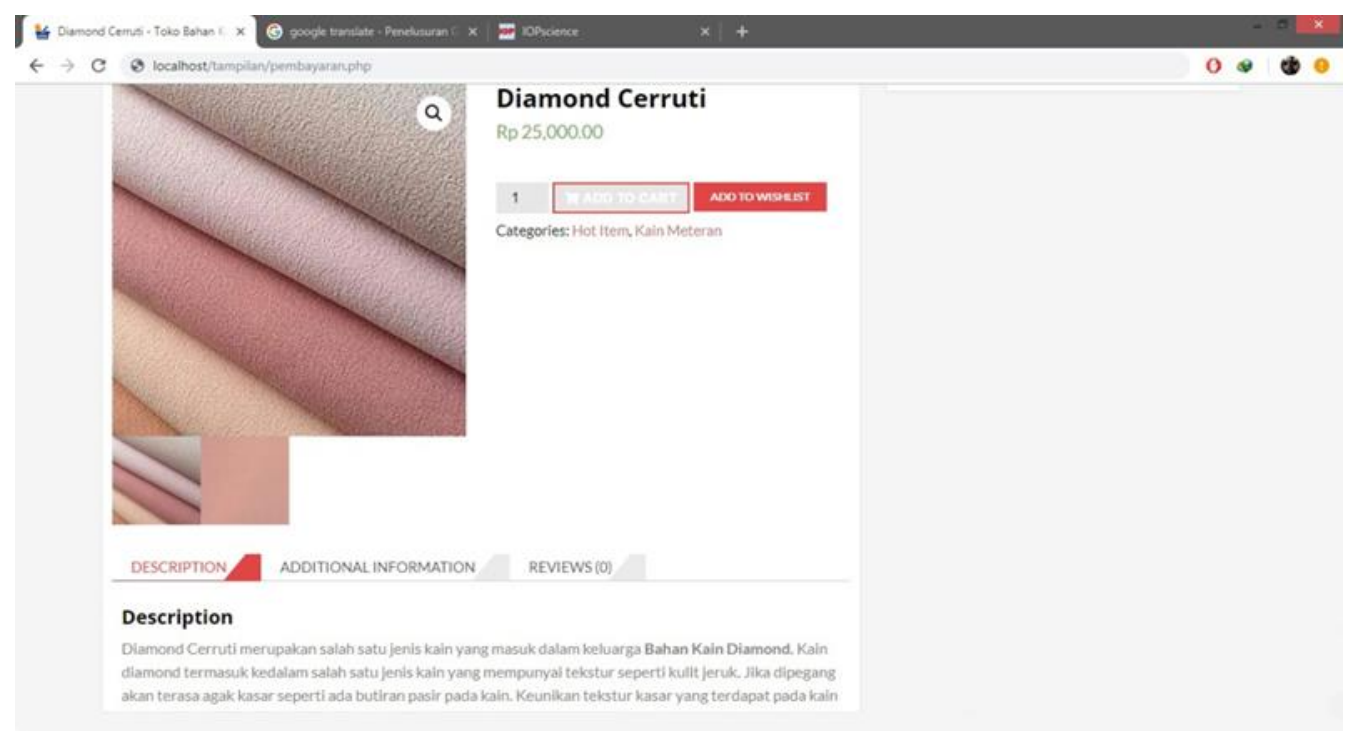

Fig. 3. Type of fabric, this figure was adopted on 12 December 2018

For the last stage, the website displays the seller's contact view, location, email, and profile of the industrial company where buyers can make contact directly through Whatsapp to make transactions. The following is an example of these websites in figure 4: 


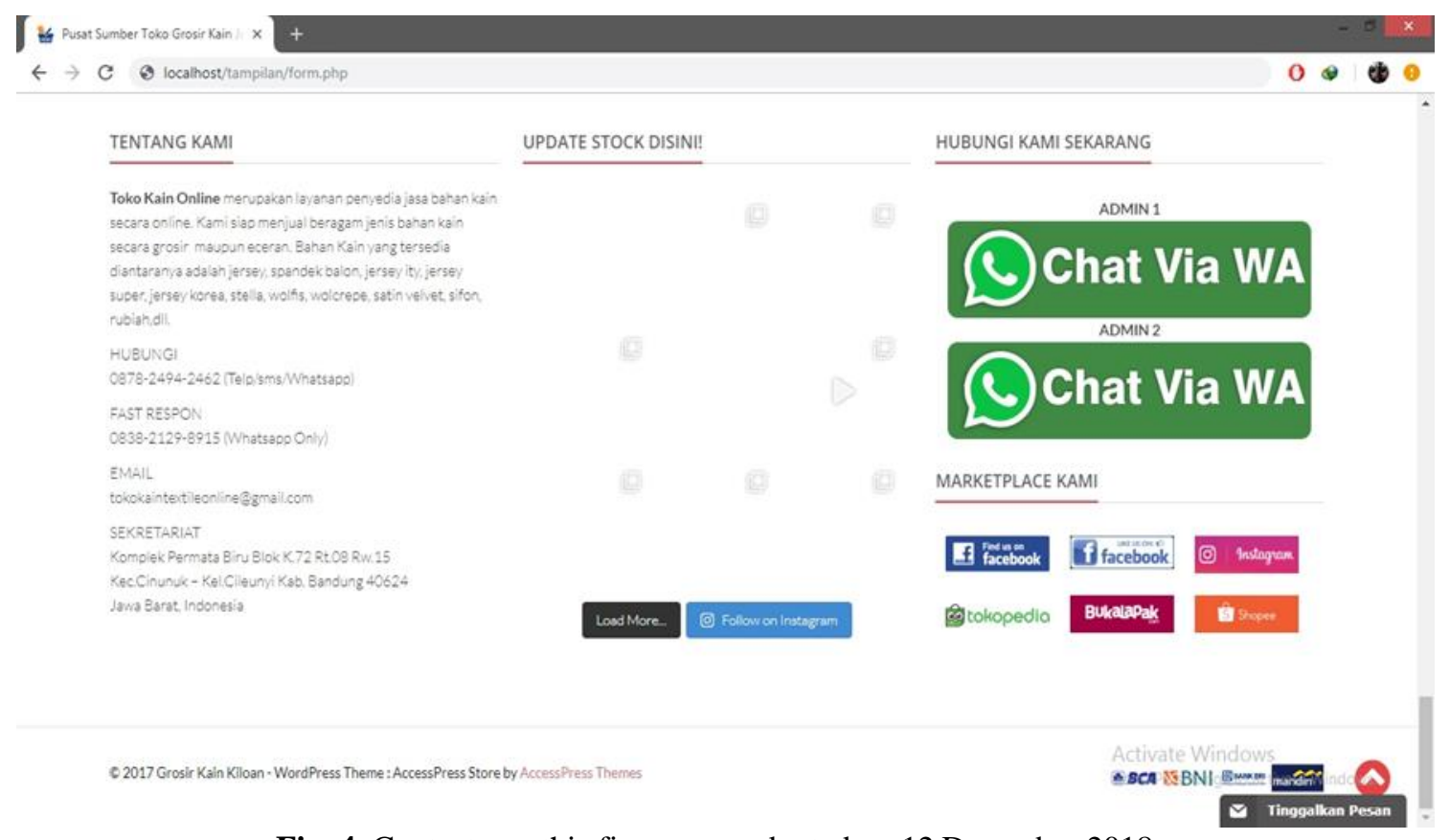

Fig. 4. Contact me, this figure was adopted on 12 December 2018

From the results of the system proposed by author, therefore it is aimed at all Internet users or industrial companies in other fields to be directed into companies that promote sustainable business. Today, it is expected that website users can expand their business network which can exceed or have a larger profit.

\section{Conclusion}

From the results of the research above, it can be concluded that the role of e-commerce in the business world greatly influences the world of business more specifically in the field of marketing that has been proven to improve the quality of marketing itself and create benefits for industrial companies. E-commerce makes it easier for customers to access information about fabric products online in an attempt to assist buying and selling of the desired fabric products to be more effective and efficient.

\section{Acknowledgements}

The author thanks those who have provided motivation to study or make this paper which has helped in writing this paper, Hopefully this article can also motivate many people, especially in the textile industry. 


\section{References}

[1] Aulia, D., \& Ikhwana, A.: Perencanaan strategi pengembangan usaha kain tenun sutra dengan pendekatan metode balanced scorecard (studi kasus di pabrik Sutra Tiga Putra). Jurnal Kalibrasi, 10(1) ) (2013)

[2] Soegoto, Eddy Soeryanto: Entrepreneurship: Menjadi Pebisnis Ulung. Elex Media Komputindo, (2009)

[3] Bernal-Merino M: Quantum identity and the enhancement of communication. Journal of Brand Strategy, 6(4) pp. 380-391 (2018)

[4] Ahmed Z., et al.: Effect of Brand Trust and Customer Satisfaction on Brand Loyalty in Bahawalpur, Journal of Sociological Research, Vol.5, p.1948-5468 (2014)

[5] Klopping, I. M., \& McKinney, E.: Extending the technology acceptance model and the task-technology fit model to consumer e-commerce. Information Technology, Learning \& Performance Journal, 22(1) (2004)

[6] Mahadevan, B.: Business Models for Internet-Based E-Commerce: An Anatomy. California Management Review, 42(4), 55-69 (2000)

[7] Subramani, M., \& Walden, E.: The impact of e-commerce announcements on the market value of firms. Information Systems Research, 12(2), 135-154 (2001)

[8] McKnight, D. H., \& Chervany, N. L.: What trust means in e-commerce customer relationships: An interdisciplinary conceptual typology. International journal of electronic commerce, 6(2), 35-59 (2001)

[9] Schafer, J. B., Konstan, J., \& Riedl, J.: Recommender systems in e-commerce. In Proceedings of the 1st ACM conference on Electronic commerce (pp. 158-166). ACM (1999)

[10] Ngai, E. W., \& Gunasekaran, A.: A review for mobile commerce research and applications. Decision support systems, 43(1), 3-15 (2007)

[11] Soegoto, E. S., \& Pamungkas, R. S.: Web-based Information System Services in a Textile Industry. In IOP Conference Series: Materials Science and Engineering (Vol. 407, No. 1, p. 012060). IOP Publishing (2018) 